\section{ELECTION RESULTS}

The results of the elections for the ASMS Board of Directors are as follows: Christie G. Enke, Vice-President for Programs (President Elect), Barbara S. Larsen, Treasurer, and Kenneth L. Busch and Jack D. Henion, Members-at-Large. The newly elected board members replace P. Jane Gale, Michael T. Bowers, and Robert C. Cotter.

As Treasurer Jane Gale formulated a plan for the management of ASMS assets to optimize returns and assure both immediate operating and long-term goals. She also was active with the Student Travel Stipend Program and Chaired the Committee which reviewed the Travel Fund requests for the Kyoto ' 92 Conference. Robert Cotter provided key leadership in the implementation of ASMS educational programs. He chaired the Education Committee which oversees the Short Courses and suggests topics for the Fall Workshops. He also spearheaded the formation of a committee charged specifically with responsibility for the Sanibel Conference. Michael Bowers chaired the Committee on Standards and Measurements which addressed a number of nomenclature issues during his tenure.

Ronald A. Hites retires from the board following his tenures as Vice-President for Programs, President, and Past President. Ron's service has made a lasting impact on ASMS programs. He provided leadership in all aspects of ASMS and it was through his initiative that the Journal of the American Society for Mass Spectrometry was established.

Robert $\mathrm{C}$. Murphy turns over the responsibilities of President to Henry M. Fales. Bob has been particularly involved in promoting the success of the journal, as well as addressing issues of eduration and funding in mass spectrometry research. He has devoted enormous amounts of time and effort to ASMS business and programs, providing the type of leadership necessary for the success of the broad range of ASMS activities. His initiatives have included the key word index for the Proceedings, the Preliminary Program on computer diskette, the Award for a Distinguished Contribution in Mass Spectrometry, and formalization of the Sanibel Cunference. He continues his interest in ASMS by co-chairing the 1992 Fall Workshop on Electrospray Ionization.

\section{THE 9TH ASILOMAR CONFERENCE ON MASS SPECTROMETRY}

This conference will be held September 27-October 1, 1992, at the Asilomar Conference Center, Pacific Grove, California. The topic is Trapped Ions, Principles, Instrumentation and Applications, and is cochaired by R. Graham Cuoks and Alan G. Marshall.

The Asilomar Conference on Mass Spectrometry
(ACMS) is an international research conference for the in-depth discussion of a selected topic in mass spectrometry. The meeting takes place in an informal setting on the scenic Montercy Peninsula, formatted to encourage uninhibited discussions and audience participation with the intent of stimulating new ideas.

The scienlific program will cover recent developments in ion chemistry and analytical measurements made on trapped ions, including Fourier transform ion cyclotron resonance and Paul ion traps as well as less common devices. The program will consist of about 25 oral and 30 poster presentations, all by invited contributors. Ample time will be allocated for discussions.

The topics covered will include the principles of operation, including simulations of ion motion; current instrumentation and prospects for enhanced performance; and analytical applications including biological mass spectrometry. Attendance is limited to 150 conferees. The conference fee, which includes registration fee, four days of room with three meals a day, banquet dinner, and refreshments during coffee breaks, is $\$ 375$ for conferees, $\$ 265$ for qualifying students and accompanying guest, and $\$ 170$ for children of age 2-17. Application deadline is August 21, 1992.

For further information contact Dr. Laszlo Tokes, Syntex Research, 3401 Hillview Avenue, Palo Alto, CA 94304; (415) 855-5713, FAX: (415) 354-7363.

\section{THE ASMS FALL WORKSHOP}

This workshop, on Electrospray Ionization, will be held November 20-21, 1992, at the Westin Copley Place, in Boston, Massachusetts. The workshop will be organized by James $\mathrm{A}$. McCloskey and Robert $\mathrm{C}$. Murphy. A distinguished faculty who have pioneered the development and applications of electrospray ionization will examine the analysis of biological compounds from low molecular weight pharmaceuticals to high molecular weight proteins. Emphasis will be placed on the practical aspects of methodolngy, such as sample preparation, factors which affect ion yield, and molecular weight determination from multiply charged ions, as well as the use of electrospray directly coupled to high performance liquid chromatography and electrophoresis. An overview of instrumental hardware design and theory of ion formation will be presented. Strategies to involve electrospray ionization in the solution of difficult problems in biotechnology will be discussed.

\section{THE 5Th SANIBEL CONFERENCE}

This conference is set for January 23-26, 1993. The topic will be Mass Spectrometry of Carbohydrates and will be organized by Vernon Reinhold, Harvard School 
of Public Health. The program will include evening poster sessions plus oral sessions each morning. Each morning's oral session will commence with a carbohydrate expert who will define glycosylation significance and functional relationships. These key lectures will be presented by Professors Harry Schlater (Hospital for Sick Children, Toronto), Finn Wold (University of Texas Medical School), and Gerald Hart (Johns Hopkins University). The keynote lectures will be followed by a series of 30-minute talks by mass spectroscopists actively involved in carbohydrate structural problems,

\section{CALENDAR OF EVENTS}

\section{2}

September 27October 1

October 20-21
The 9ti Asilomar Conference on Mass Spectrometry, "Trapped Ions: Principles, Instrumentation \& Applications. Program Chairs: R. Graham Cooks and Alan G. Marshall. Contact: Laszlo Tokes (415) 855-5713.

Pacific Conference on Chemistry \& Spectroscopy, Holiday Inn, Foster City, California. Contact: Peter Palmer (415) 604-3615.

November 20-21 ASMS Fall Workshop, Electrospray Ionization. Westin Hotel Copley Place, Boston, Massachusetts.
The conference will focus on oligosaccharide structures of all glycoconjugate types, including glycoproteins and glycolipids. The conference intends to bring together a cross section of researchers to discuss deglycosylation, sequence, branching, linkage, sensitivity, fragmentation, ionization methods, and mass spectrometry interfacing including CE and capillary and micropore high performance liquid chromatography. Emphasis will be on the practical problems involved in glycotype and glycoform profiling of commercial recombinant products and the details of structure-function relationships.

1993

January 23-26 Sanibel Conference on Carbohydrates, Sundial Resort, Sanibel Island, Florida.
May $30-$ June 4

\author{
41st ASMS Conference on Mass \\ Spectrometry, San Francisco, Cali - \\ fornia.
}

ASMS News is prepared by Judith A. Sjoberg, Post Office Box 1508, East Lansing, MI 48826, (517) 3372548. 